\title{
ANALISIS WACANA KRITIS DI MEDIA SOSIAL (STUDI PADA FENOMENA PRO-KONTRA PENOLAKAN DAKWAH USTADZ ABDUL SOMAD)
}

\author{
BAITI RAHMAWATI, ABDUL MUHID \\ Universitas Islam Negeri (UIN) \\ Sunan Ampel Surabaya \\ Email: Baitirahma02@gmail.com \\ Email: abdulmuhid@uinsby.ac.id
}

\begin{abstract}
:
$D a$ 'wah and technological development are inseparable, this is based on the concept of contemporary da'wah that is easily accepted by the present, various new phenomena such as the case of rejection of clerics in several regions arise along with the rise of activity on social media, which incidentally is full of information which is not necessarily true (Tornberg \& Tornberg, 2016: 132-134). The news of the pros and cons of rejecting the da'wah experienced by Ustadz Abdul Somad was forwarded freely on social media, one of the social media is twitter. In analyzing discourse on social media, especially Twitter, the author uses analysis technic of critical discourse analysis theory by Norman Fairclough to dismantle discourse practices (Eriyanto, 2015: 285), and includes Antonio Gramsci's theory of hegemony to see discourse battles (Ives, 2004: 63) in the phenomenon of Ustadz Abdul Somad's rejection. The results of this study include: (1) The issue of the affiliation of Ustadz Abdul Somad can be mediated with tabayyun and clarification through the media, both traditional and social. However, the issue of khilafah is growing until it displays a process of mutual accusation between the parties involved in the discourse of the khilafah revival; 2) The discourse of Ustadz Abdul Somad's rejection on social media in this study contains trends from two different ideologies namely Nahdlatul Ulama (NU), and Hisbut Tahrir Indonesia (HTI (3) The other tendencies are also influenced by political interests; 4) Between HTI and Banser has an impact on the image of Prabowo's and Jokowi's strongholds with the issue of the fight. HTI was identified as part of opposition supporters, while the impact on the Jokowi camp with antiIslamic issues, because it was deemed not to show an attitude to clean up the chaos caused by burning the flag at the commemoration of the "Hari Santri Nasional.
\end{abstract}

Keywords: Critical Discourse Analysis, Hegemony, Twitter 


\section{PENDAHULUAN}

Dakwah dan perkembangan teknologi tidak dapat dipisahkan, hal ini dipijakkan pada konsep dakwah kontemporer yang mudah diterima oleh kalangan masa kini. Masyarakat dengan mudah mendapatkan informasi keagamaan dari internet. Bagi sebagian orang yang tidak memiliki kesempatan datang ke kajian ceramah, solusi terbaik bagi mereka adalah dengan mendengarkannya melalui media sosial. Media sosial dianggap sebagai wadah yang memiliki kekuatan diskursif dalam masyarakat (Tornberg \& Tornberg, 2016: 132-134).

Banyak sekali $d a$ ' $i$ yang memiliki ciri khas serta popularitas yang tinggi, di antaranya, Buya Hamka dengan keahlian agama dan ketegasannya; KH. Zainuddin MZ yang dikenal sebagai $d a$ 'i sejuta umat; KH. Abdullah Gymnastiar (Aa Gym) dengan ceramahnya yang santun; Arifin Ilham dengan senjata dzikir yang disenangi masyarakat; dan bersamaan dengan boomingnya media sosial, tumbuh juga seorang $d a{ }^{\prime} i$ yang memiliki daya tarik besar, yaitu Ustadz Abdul Somad, Lc atau dikenal dengan nama UAS (Quraisy, 2018). UAS adalah ulama' yang berasal dari Sumatera Utara yang sering mengulas berbagai macam persoalan agama, nasionalisme serta berbagai masalah yang sedang menjadi pembahasan di masyarakat.

Nama Ustadz Abdul Somad mulai dikenal di masyarakat karena kelugasannya dalam berdakwah, potongan-potongan atau full-video ceramahnya banyak di-upload melalui saluran youtube kemudian disebarluaskan lagi ke media sosial yang lain (Bambang, 2018). Selain banyak yang menyukai gaya ceramah ustadz Abdul Somad, adapula yang menolak bahkan menentang dakwahnya. Tetapi di balik itu semua, ia tetap berdakwah ke berbagai daerah hingga pelosok lalu mengunggah setiap kegiatan dan isi ceramahnya. Di antara penolakan itu antara lain, Protes dari ormas yang tergabung dalam Komponen Rakyat Bali (KRB) yang menganggap ustadz Somad anti-Pancasila dan pro-khilafah (SUO2, 2017). Tidak lama setelah penolakan di Bali, kembali viral di media sosial pada tanggal 23 Desember 2017 bahwa UAS ditolak masuk Hongkong oleh otoritas setempat setibanya di bandara (Solusi, 2017). Dan yang masih hangat adalah isu tentang intimidasi dan juga persekusi atas UAS di beberapa daerah di Jawa Tengah dan Jawa Timur (ARN, 2018). Sebagai penerus ajaran Nabi Saw para pembaharu ini mengalami berbagai ujian dan cobaan, difitnah dan dicaci maki namun tidak mundur dalam menjalankan amanah mengabdi kepada umat memperbarui ajaran Islam sehingga Islam itu "sholihun likulli zaman wa makan" (Hosen, 2018: 308).

Wacana penolakan dakwah UAS dalam praktiknya di media sosial banyak dikaitkan dengan oposisi, Kepedulian pengguna twitter ketika memposting teks lebih banyak menyandingkannya dengan tanda \#2019gantipresiden. Penolakan 
serta intimidasi yang dialami ustadz Abdul Somad beriringan dengan eksisnya tahun politik capres cawapres 2019. Selain itu juga dibenturkan dengan beberapa organisasi masyarakat yang berkembang di Indonesia. di antaranya Nahdlatul Ulama' dan juga HTI, seperti peristiwa di Bali, Ustadz Abdul Somad dikawal oleh PWNU Bali, namun ketika ditolak ceramah isu yang berkembang seakan PWNU menghalangi dakwah Ustadz Abdul Somad (Mumazziq, 2017).

Dalam konteks pertarungan kepentingan ataupun ideologi, proses interaksi ini menyaratkan adanya pihak yang dikuasai dan menguasai, banyak faktor yang menyebabkan seseorang menjadi penguasa atau malah dikuasai, di antaranya karena faktor ekonomi, politik, pengetahuan, maupun sosial (Azizi, 2017: 54). Media seakan-akan menggiring khalayak dengan memproduksi rekayasa persetujuan (engineering of concent) (Barker, 2011: 63) bahwa UAS pro-Khilafah dan anti-Pancasila, sedangkan Pancasila dan NKRI adalah bentuk final dalam kehidupan berbangsa dan bernegara, Wacana ini juga dibenturkan dengan organisasi masyarakat serta oposisi tertentu yang juga saling menyerang maupun bertahan, sekalipun keterkaitan UAS dengan isu khilafah sudah diklarifikasi (Mumazziq, 2017).

Hal inilah yang menarik penulis untuk melakukan penelitian dengan judul tersebut di atas. Dalam menganalisis wacana kritis, penulis menggunakan metode Critical Discourse Analysis yang dikemukakan oleh Norman Fairclough (kriyantono, 2012: 256), bidang utama yang menarik dalam analisis wacana kritis yang digunakan oleh Fairclough adalah penyelidikannya terhadap perubahan. Penggunaan bahasa selalu berdasarkan struktur kewacanaan karena pengguna bahasa membangunnya berdasarkan makna yang telah mapan). Dalam penelitian ini, berita yang diambil berupa topik-topik terpisah dari twitter melalui hashtags sentimen, teks sentimen, dan nama pengguna, yang meskipun tidak menjelaskan penolakan dakwah UAS secara langsung, namun sering diangkat dan didiskusikan secara pararel dengan diskusi tentang "khilafah." Isu khilafah semakin intens dan terbuka dikampanyekan, seperti mewacanakan Islam sebagai solusi dan ideologi alternatif dalam pemerintahan Indonesia dari negara kesatuan berformat republik menjadi khilafah (Ghofar, 2015: 5). Dengan jalan menggabungkan unsur-unsur yang berasal dari wacana yang berbeda itulah penggunaan bahasa konkret dapat mengubah wacana individu, dengan demikian juga mengubah dunia sosial serta kulturalnya (Eriyanto, 2015: 2).

Media dan wacana adalah dua hal yang saling mendukung. Keberadaan wacana bergantung pada media yang melingkupinya, dan media bergantung pada penikmat atau penggunanya. Bagi peneliti, sebagaimana yang dikatakan oleh Fairclough, konsep hegemoni merupakan alat Yogyakartayang bisa digunakan 
untuk menganalisis bagaimana praktik kewacanaan menjadi bagian dari praktik sosial yang melibatkan hubungan kekuasaan: praktik kewacanaan bisa dipandang sebagai aspek perjuangan hegemonis yang memberikan kontribusi bagi reproduksi dan transformasi tatanan wacana. Suatu wacana selalu berkelindan dengan berbagai tingkatannya: dalam situasi langsung, institusi atau organisasi dalam tingkatan masyarakat (Haryatmoko, 2016: 24)

\section{Teori Analisis Wacana Kritis dan Teori Hegemoni}

Analisis wacana kritis banyak dikembangkan oleh para ahli seperti Roger Folwer dkk, Theo Van Leeuwen, Sara Mills, Teun A. Van dick dan Norman Fairclough. Analisis yang dipakai oleh penulis dalam penelitian ini adalah analisis yang dikembangkan oleh Norman Fairclough, seorang Sosiolinguistik Inggris, pada tahun 1980-an. Analisis wacana kritis merupakan sebuah teori atau pendekatan yang digunakan untuk menganalisis sebuah teks dalam konteks sosiokultural, yang di dalamnya secara rinci membahas mengenai praktik sosial yang ada dalam media. Oleh karena itu, model yang dikemukakan oleh Norman Fairclough ini sering disebut sebagai model perubahan sosial (social change) (Eriyanto, 2015: 285).

Kemunculan Analisis Wacana Kritis bertepatan dengan pertumbuhan paradigma/teori/disiplin penting lainnya dalam ilmu sosial, seperti Psikologi Kritis; dan Kebijakan Sosial Kritis. Analisis Wacana Kritis/Critical Discourse Analysis (AWK/CDA) mulanya memiliki label alternatif seperti, Kesadaran Bahasa Kritis atau Studi Bahasa Kritis, Fairclough juga menggunakan label Linguistik Kritis. Dalam konteks ini, istilah kritis dapat dilihat untuk menandai genre khusus studi akademis dan implikasi apa yang dibawa oleh label ini (Weiss \& Wodak, 2003: 47). Istilah Critical Linguistic (CL) dan Critical Discourse Analysis (CDA) sering digunakan secara bergantian. Bahkan akhir-akhir ini tampaknya istilah CDA lebih disukai dan digunakan untuk menunjukkan teori yang sebelumnya diidentifikasi sebagai Critical Linguistic CL (Wodak \& Meyer, 2001: 1).

Secara lengkap analisis Norman Fairclough meliputi dimensi berikut (Jorgensen \& Louise, 2007: 123):

a) Teks

Dalam model Fairclough ini teks dianalisis secara linguistik, dengan melihat kosa-kata, tata bahasa dan metafora. Selain itu, dalam model ini juga menampilkan koherensi dan kohesivitas, yakni bagaimana antar-kata atau antar-kalimat digabung menjadi sebuah pengertian.

b) Discourse practice 
Analisis Discourse Practice merupakan analisis wacana yang membahas bagaimana sebuah teks diproduksi dan dikonsumsi. Kedua hal tersebut berkaitan dengan jaringan komplek antar-teks yang terlibat di dalamnya (intertekstualitas), praktik-praktik ini berkaitan dengan teks yang dihasilkan serta diterima dan diiterpretasikan oleh pembaca.

c) Sociocultural practice

Sociocultural practice merupakan dimensi yang berhubungan dengan konteks di luar teks. Konteks di sini memainkan beberapa hal, seperti konteks situasi mengenai praktik institusi dari media yang berhubungan dengan masyarakat, budaya dan politik tertentu. Analisis wacana kritis digunakan sebagai pemakaian bahasa dalam tuturan dan tulisan ataupun sebagai bentuk dari praktik sosial. Dalam hal ini, wacana tidak hanya dilihat pada studi bahasa saja, tetapi juga berkaitan dengan konteks yang ada dalam masyarakat.

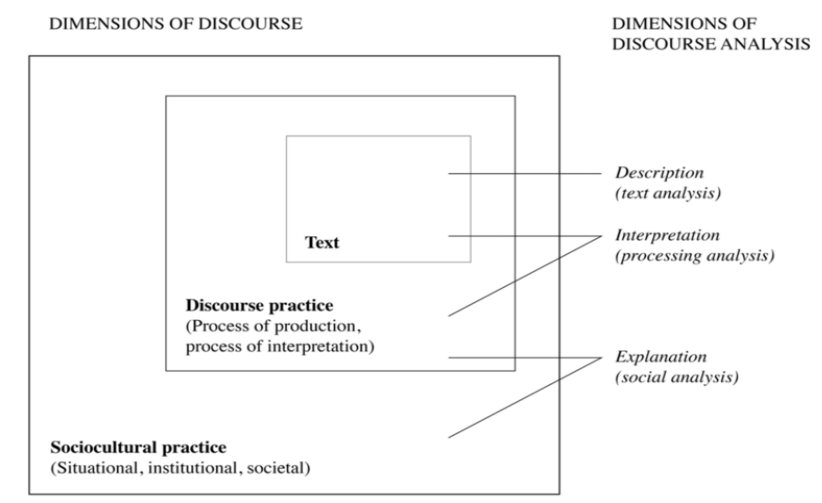

Gambar 2.1. Dimensi Wacana Kritis Norman Fairclough

Hegemoni adalah tentang cara menerapkan kekuasaan ideologi yang tidak terlihat, yakni proses di mana terdapat perjuangan untuk mencapai dominasi di antara kelompok social (Burton, 2012: 73). Istilah hegemoni memiiki sejarah Panjang sebelum Gramsci, berasal dari kata 'hegemon' yang secara harfiah berarti pemimpin, otoritas dan dominasi (Ives, 2004: 63). Bagi Gramsci, hegemoni berarti situasi di mana suatu 'blok historis' faksi kelas atas yang berkuasa menjalankan otoritas kepemimpinan dan sosial atas kelompok subordinat melalui kombinasi kekuasaan dan persetujuan (Barker, 2011: 62). Sebelum Gramsci istilah 'hegemoni' kurang lebih terbatas pada arti dominasi satu bangsa terhadap yang lain. Namun sekarang hegemoni digunakan untuk menggambarkan seluk beluk hubungan kekuasaan di berbagai bidang, mulai sastra, Pendidikan, film dan studi budaya hingga politik (Ives, 2004: 2).

Sejalan dengan pendekatan kritis, perspekif hegemoni Gramsci besar pengaruhnya terhadap analisis wacana kritis (AWK) karena kekuasaan digambarkan melalui suatu bahasa yang mengandalkan persetujuan tanpa adanya 
koersi (paksaan), artinya bentuk pengorganisasian persetujuan dengan kesadaran dibangun tanpa kekerasan, namun melandaskan pada budaya dan persuasi intelektual, yang dalam AWK landasannya adalah analisis teks (Haryatmoko, 2016: 2).

Dalam media sosial, selain sebagai konsumen, pengguna/user juga berperan sebagai produsen. Mereka memilih sendiri teks apa yang akan dibuat, diterima, serta dimaknai. Meskipun pengguna memiliki kuasa atas teks, namun itu semua tidak dilakukan dalam bingkai pilihan yang mereka susun sendiri, melainkan terbentuk di luar jangkauan intervensi mereka (Eriyanto, 2015: ix ). Struktur sistem produksi, rasionalitas, maupun metanarasi (ideologi) dalam produksi teks tidak cukup dikenali dengan teks mentah saja, sehingga dalam penelitian ini digunakan metode tersendiri untuk menggali ideologi yang termuat dalam teks, dengan menggunakan analisis wacana kritis dan kombinasinya dengan analisis hegemoni untuk melihat nilai-nilai pertarungan dari wacana yang ditampilkan mengenai Ustadz Abdul Somad.

Bahasa biasa dipahami sebagai alat komunikasi, bahkan oleh Bourdieu bahasa dilihat sebagai instrument kekuasaan, karena hubungan sosial pada dasarnya adalah hubungan dominasi. Sebagai interaksi simbolis, hubungan komunikasi mengimplikasikan adanya hubungan antara pengetahuan dan kekuasaan (Haryatmoko: 3-4). Bahasa sebagai alat hegemoni memberikan gambaran yang lebih jelas tentang paksaan atau persetujuan sebagai cara kita memandang dunia. Dalam penelitian ini sebuah bahasa digunakan oleh suatu kelompok yang merepresentasikan dirinya sebagai pihak yang tidak hanya mampu memenuhi kepentingan sendiri namun juga kebutuhan dan kepentingan kelompok sosial. Cara seperti ini dilakukan dengan melakukan 'transformismo' yaitu memasukkan nama-nama orang yang berpengaruh atau pemimpin kelompok sosial dalam jaringan elit mereka. Di sini hegemoni terlihat sebagai dominasi melalui kata-kata. Kerangka Berfikir teori Analisis wacana Kritis dan Hegemoni dalam penelitian ini digambarkan dalam bagan berikut: 


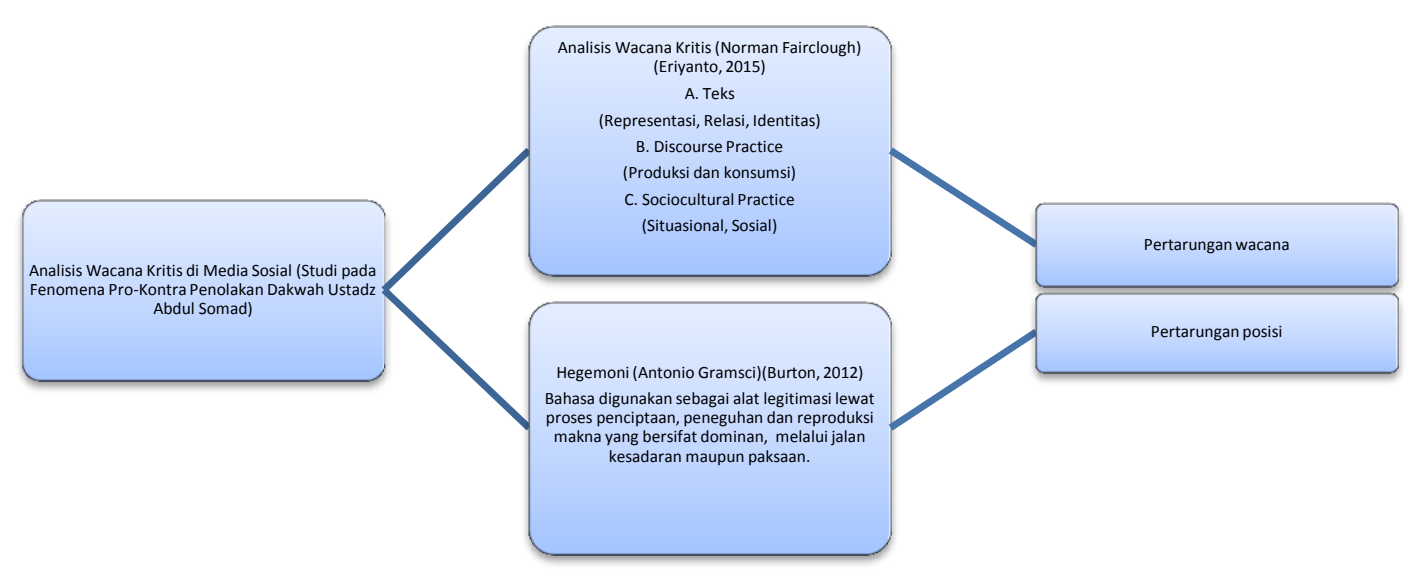

\section{Sekilas tentang Penolakan Dakwah Ustadz Abdul Somad}

Ustadz Abdul Somad, LC., MA lahir di Silo Lama-Asahan-Sumatra Utara pada hari Rabu, 30 Jumadil Awal 1397, bertepatan dengan 18 Mei 1977 M (Somad, 2018: 443). Namanya dikenal publik karena ilmu dan kelugasannya dalam memberika materi ceramah, mulai masalah agama, juga membahas mengenai nasionalisme dan berbagai masalah terkini yang sedang menjadi pembahasan dalam masyarakat. selain menjadi $d a^{\prime} i$, laki-laki yang akrab dipanggil UAS ini bertugas sebagai dosen di Universitas Islam Negeri Sultan Syarif Kasim (UIN Suska) Riau. Secara singkat, perjalanan intelektual ustadz Abdul Somad di mulai dari SD al-Washiliyah Taman pada tahun 1990; Madrasah Tsanawiyah Mu'allimin al Washliyah Medan, tamat pada 1993; Madrasah Aliyah Nurul Falah tamat pada tahun 1996; sarjana strata satu ditempuh di al-Azhar Mesir, ia merupakan salah satu dari 100 orang yang menerima beasiswa dari pemerintah Mesir di Universitas Al-Azhar; dan berlanjut Strata dua di Dar alHadits al-Hassania Institute, Kerajaan Maroko tahun 1998, juga melalui jalur beasiswa dari AMCI (Agence Marocaine Cooperation Internationale) (Arifin \& Maulana, 2017: 11). Penolakan dakwah yang dialami oleh Ustadz Abdul Somad antara lain:

a) Penolakan Dakwah di Bali

Republika.co.id Denpasar melaporkan "Ustadz Abdul Somad sempat ditolak oleh organisasi masyarakat Bali." Sejumlah ormas di Bali yang menamakan dirinya sebagai Komponen Rakyat Bali (KRB) menolak kegiatan dakwah Ustadz Abdul Somad pada jumat, 8 Desember 2017. Puluhan orang anggota KRB berunjuk rasa di halaman Hotel Aston Denpasar di mana Ustadz Abdul 
Somad menginap. Ustadz Abdul Somad dijadwalkan mengisi pengajian di masjid An-Nur, alasan yang ditujukan oleh Laskar Bali karena Ustadz Somad tidak cinta NKRI dan mendukung tegaknya sistem khilafah di Indonesia. Selain Republika, Detik.com juga memuat kabar yang sama, bahwa kehadiran UstadzAbdul Somad sempat diprotes oleh ormas yang tergabung dalam Komponen Rakyat Bali (KRB), massa masuk ke loby hotel untuk melakukan mediasi, namun gagal menghasilkan solusi sehingga jajaran Polresta Denpasar-pun turun ke lokasi untuk melakukan mediasi ulang.

b) Penolakan Dakwah di Hongkong

Jakarta, CNN Indonesia- Ustadz Abdul Somad ditolak masuk Hong Kong oleh otoritas setempat setibanya di bandara, Sabtu 23 Desember 2017 sedianya ia dijadwalkan untuk mengisi ceramah di kelompok Tenaga Kerja Indonesia yang berada di Hong Kong. Ustadz Abdul Somad bersama dua rekannya diperiksa pihak imigrasi setempat dan hari itu juga diminta meninggalkan Hong Kong. Melalui akun Facebooknya, Ustad Abdul Somad menjelaskan kronologi penolakan otritas Hong Kong, di mana ia ditarik dari rombongan penumpang oleh sejumlah orang tak berseragam lalu diminta menunjukkan dompet beserta identitas di dalamnya, ia dimintai keterangan mengenai identitas, pekerjaan dan Pendidikan, hingga keterkaitan dengan ormas dan politik. Di antara yang paling lama ditanya adalah kartu nama Rabithah Alawiyah (Ikatan Habaib), di sanalah Ustad Abdul Somad menduga mereka tertelah isu terorisme, karena ada logo bintang dan tulisan Arab, lebih kurang 30 menit berlalu, mereka mengungkapakan bahwa negara mereka tidak bisa menerima saya, itu saja tanpa alasan," ungkapnya.

c) Penolakan dakwah di beberapa Daerah Jawa

Berita intimidasi dan persekusi Ustadz abdul Somad (UAS) ramai diperbincangkan di media sosial sejak awal bulan September, yaitu ketika beredar kabar pembatalan ceramah yang dilakukan oleh UAS di beberapa kota di Jawa Timur dan Jawa Tengah. Hal ini kemudian diklarifikasi oleh UAS lewat akun instagramnya pada 2 September 2018 dengan alasan bahwa kegiatan dakwah UAS sebelumnya di beberapa kota di Jawa Tengah (Grobogan, Kudus, Jepara, dan Semarang) mendapat tekanan, ancaman, intimidasi, serta upaya pencekalan dakwah, hal ini menyebabkan beban psikologis panitia, jamaah serta Ustadz Abdul Somad sendiri. Beberapa asumsi terkait pencekalan ini antara lain: (a) label anti kebhinekaan dan anti NKRI; dan (b) adanya organisasi tertentu yang menunggangi kegiatan ceramah. Polemik itu muncul setelah ada unggahan foto di media sosial yakni sekelompok yang mengenakan topi serta atribut bersimbol HTI (Setiawan, 2018). 


\section{PEMBAHASAN}

\section{Dinamika Politik Kekuasaan Masa Pra-Pemilu}

Sebagaimana kita ketahui, bahwa pemilihan presiden dilakukan pada bulan April 2019, namun beberapa partai politik peserta pemilihan presiden mulai melakukan kampanye, sebagai salah satu bagian komunikasi politik sesuai dengan nilai yang ada. Salah satu bentuk kampanye yang sedang diperbincangkan adalah gerakan bertagar\# PrabowoUAS; \#2019gantipresiden dan juga \#2019TetapJokowi.

Ustadz Abdul Somad (UAS) diusulkan menjadi cawapres Prabowo Subianto lewat ijtima' Ulama (Ibrahim, 2018), namanya terus menguat dan dianggap bisa menjadi jalan tengah dari kebuntuan politik antara partai Gerinda, PAN, dan PKS dalam mengusung cawapres Prabowo dalam pilpres 2019. Pasangan Prabowo-UAS dinilai sebagai kombinasi yang saling melengkapi karena berlatar belakang Nasionalis-Agamis, serta dapat memberikan pengaruh signifikan untuk menarik para pemilih religius di Indonesia. Namun dari segala kelebihan itu, pengusulan nama Ustad Abdul Somad juga menjadi pertimbangan yaitu pada kemampuan logistik Ustadz Abdul Somad tidak sebesar yang ditawarkan oleh nama-nama cawapres yang diusung oleh partai koalisi lainnya (Rahadian, 2018). Terkait dengan pengusulan namanya, UAS menghormati rekomendasi yang diberikan oleh ijtima' ulama, dan menyatakan bahwa ingin istiqomah di jalan dakwah dan pendidikan saja (Tafaqquh, 2018). Perbincangan tentang cawapres 2019 mendapatkan perhatian dari netizen terutama pengguna twitter.
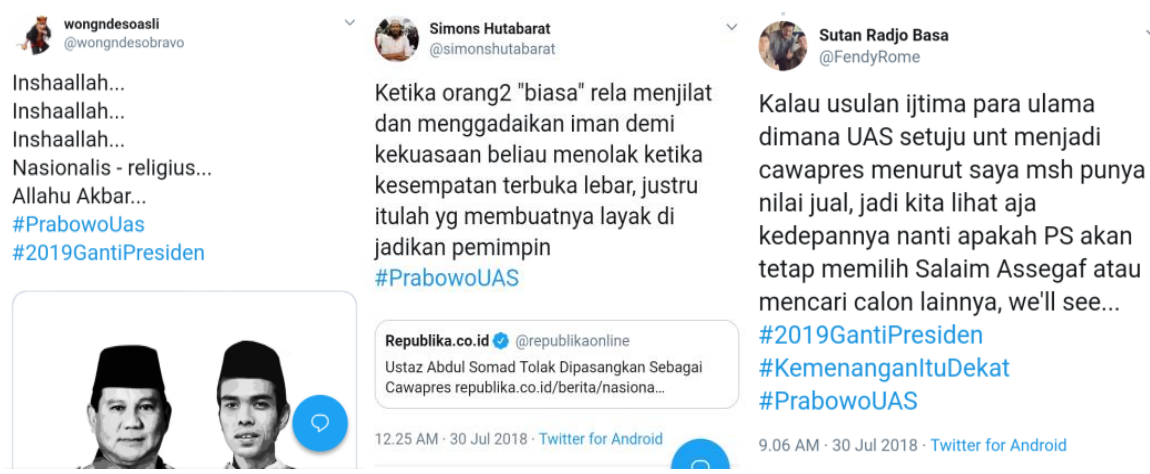

Gambar 1. Tweet tentang rekomendasi nama Ustad Abdul Somad sebagai cawapres Prabowo Subianto (sumber data primer www.twitter.com)

Tweet pertama diposting oleh akun @wongndesobravo yang merepresentasikan Prabowo Subianto dan Ustadz Abdul Somad (UAS) sebagai pasangan yang tepat untuk dalam pesta demokrasi 2019. Secara representasi, 
tweet ini menggunakan dua bentuk matafora positif, yaitu pada kata nasionalis dan religius. Kata nasionalis diabstraksikan sebagai sikap mencintai negaranya sendiri, sedangkan 'religuis' diabstraksikan sebagai sikap yang memegang ajaran agama. Dari kedua sudut pandang di atas, penulis dapat menganalisis dari tweet ini, bahwa ada hal-hal yang hendak direpresentasikan, yaitu kata 'nasionalis' direpresentasikan untuk menggambarkan pribadi Prabowo yang berasal dari latar belakang militer, sedangkan kata 'religius' direpresentasikan untuk menggambarkan Ustadz Abdul Somad sebagai pegiat yang luas wawasan keagamaan serta populer di dunia maya maupun nyata. Citra nasionalis digunakan sebagai alat legitimasi capres ideal (Hafsi dkk, 2017), serta mencitrakan sosok pemimpin yang bertanggung jawab, pekerja keras tegas, taat hukum, rasional dan tidak otoriter.

Tweet kedua diposting oleh akun@monspower. Secara representasi, tweet ini menggunakan tata bahasa keadaan yang ditampilkan dalam anak kalimat, "Ketika orang2 "biasa" rela menjilat dan menggadaikan iman demi kekuasaan beliau menolak ketika kesempatan terbuka lebar" bentuk ini menunjuk pada sesuatu yang telah terjadi, dan hanya menggambarkan keadaan dengan menggunakan kata "ketika". Tata bahasa lainnya adalah bentuk proses mental, yang menampilkan sesuatu sebagai sebuah fenomena kepada khalayak, bahwa sekalipun UAS menolak hasil ijtima' ulama yang mengusulkan dirinya sebagai calon presiden mendampingi Prabowo Subianto, itu justru menunjukkan kharisma yang dimilliki oleh Ustadz Abdul Somad. Hal ini ditampilkan pada anak kalimat, “justru itulah yg membuatnya layak di jadikan pemimpin." Bentuk metafora yang digunakan dalam tweet ini ditampilkan pada kata 'menjilat dan menggadaikan iman' yang diabstraksikan sebagai sifat salah satu pihak yang tidak memiliki komitmen dan suka memanfaatkan kesempatan demi suatu kepentingan. Rekomendasi nama UAS menjadi cawapres menjadi wacana dominan dalam kaitan dengan kepemimpinan nasional meskipun bukan tokoh yang aktif dalam politik praktis. Selanjutnya tweet ketiga yang diposting oleh akun@FendyRome secara representasi, menggunakan tata bahasa tindakan yang digambarkan pada anak kalimat a) UAS setuju menjadi cawapres; b) PS akan tetap memilih Salim Assegaf; c) PS mencari calon lainnya, pada tiga anak kalimat ini berstruktur transitif (subjek+verb+objek). Tata bahasa lainnya yang digunakan dalam tweet ini adalah bentuk proses mental, di mana pemilik akun mencoba untuk membentuk kesadaran khalayak dengan menampilkan kata "menurut saya masih punya nilai jual." Dalam hal ini dua aktor yang ditampilkan dalam teks merupakan tokoh yang harus dipilih oleh PS (Prabowo Subianto) untuk mendongkrak elektabilitas (tingkat pemilihan publik) dalam pemilihan presiden April 2019. Selain itu, tweet ini juga menggunakan satu bentuk metafora negative yaitu pada 
kata "kata nilai jual" yang diabstraksikan sebuah komoditas politik, UAS bisa menjadi penarik massa yang besar baik hanya sebagai juru kampanye maupun kandidat dengan kombinasi kesalehan, popularitas dan politik.

\section{Wacana kriminalisasi Ulama dan Politisasi Agama}

Bangsa Indonesia memiliki corak masyarakat yang beragam (pluralistic society), kompleksititas memunculkan banyak masalah, baik ekonomi, sosial, politik, maupun agama. Suatu konflik yang melibatkan sentimen agama menjadi masalah yang marak terjadi. Massa yang terlibat di dalamnya sangat mudah terprovokasi emosinya. Dalam artikel ini, sentimen agama dimainkan dengan adanya istilah kriminalisasi ulama, muncul dalam penggunaan tagar secara berdampingan yang menyatakan rezim saat ini (pemerintahan Joko Widodo), sering mengkriminalisasi Ulama. Kriminalisasi merujuk pada pengertian proses yang semula tidak dikategorikan sebagai peristiwa pidana, namun kemudian digolongkan dengan pidana oleh masyarakat. Wacana kriminalisasi ulama atau upaya meminggirkan umat Islam menjadi isu yang krusial di Indonesia, kasus persekusi yang dilakukan oleh kelompok tertentu menimpa ulama dan aktifis Islam, yang menurut mereka dianggap mendakwahkan khilafah serta berpotensi ke arah radikalisme. Ketegangan seperti ini sudah terjadi mulai 2017 sejak Basuki Tjahaya Purnama (Ahok) mencalonkan diri sebagai Gubernur DKI Jakarta, hingga mencapai puncaknya pada tahun 2018 dengan aksi gerakan bela agama (GBA) yang berjilid menjadi reuni alumni 212. Alih-alih melawan kedzaliman dan membela Islam, terlebih pasca pembakaran bendera tauhid yang dilakukan oleh anggota Banser di Garut tahun 2018. Selain itu wacana kriminalisasi lainnya yaitu, yang dialami oleh pihak yang mengaku sebagai ulama, seperti Rizieq Syihab yang dipenjarakan karena kasus chat yang berbau sara dan sebelumnya juga terkait dengan kasus penodaan pancasila pada tabligh akbar yang diadakan oleh FPI. Rizieq Syihab sendiri merupakan tokoh yang memiliki andil besar dalam serangkaian aksi bela Islam dan bela tauhid 212. Penulis menemukan kesenjangan, di mana aksi ini, memiliki agenda tersembunyi sebagai sikap antipati terhadap pemerintah yang diangap tidak tegas dan melecehkan umat Islam. 
= Hayyivira Daisy VanBerg @... . 3 Sep

Bersiap2lah mghadapi tahun ${ }^{2}$ penuh fitnah dan tipu daya,ketika dakwah dihalangi,syiar Islam mulai dikebiri kmudian hukum2 ALLAH dikriminalisasi. JANGAN DIAM ketika agama dan ulama mulai diganggu.Perjelas posisimu, membela yg Haq atau yg bathil. \#KamiBersamaUAS \#KamiBersamaUlama

$\rightarrow$

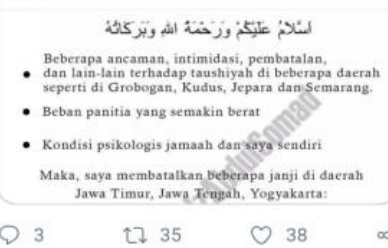

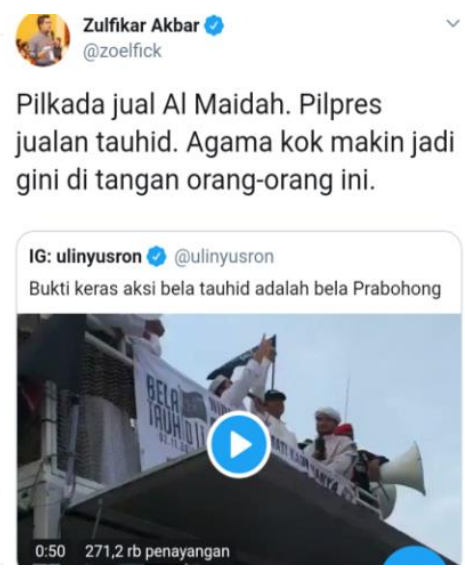

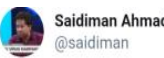

Politisasi agama adalah menjadikan agama sebagai alat dan bahan utama dalam kampanye merebut kekuasaaan. Politisasi agama adalah tindakan memperalat agama untuk kekuasaan. Dan itulah yang dilakukan oleh PKS sejak awal berdiri sampai sekarang.

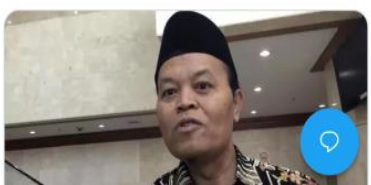

Gambar 1. Tweet tentang wacana kriminalisasi ulama dan pplitisasi agama (sumber data primer www.twitter.com)

Dalam tweet yang diposting oleh@Hayyi_ViraDaisy secara representasi, bentuk tata Bahasa yang digunakan adalah proses mental, seperti dalam kalimat, "Bersiap-siaplah menghadapi tahun-tahun penuh fitnah dan tipu daya, ketika dakwah dihalangi", kata bersiap-siaplah merupakan suatu himbauan yang ingin disampaikan pemilik akun kepada khalayak tanpa menunjuk subjek/pelaku, dan korban secara spesifik. Dari data tersebut, setidaknya terdapat relasi yang dominan pada pembatalan ceramah UAS di beberapa daerah Jawa. Pembatalan ini memiliki hubungan yang tidak sependapat dengan pihak Ansor kerena UAS merasa diintimidasi, sedangkan pihak Banser mengaku tidak melakukan pelarangan, hanya mewaspadai kalau ceramah yang dilakukan UAS ditunggangi oleh organisasi yang telah dibubarkan.

Tweet kedua diposting oleh akun@zoelfick. Secara reprsentasi, Bentuk tata bahasa yang ditampilkan adalah bentuk tata bahasa proses mental, di mana pemilik akun@zoelfick berusaha membentuk kesadaran umum kepada masyarakat bahwa terdapat dua agenda sama yang dilakukan oleh beberapa oknum tertentu menjelang dua pesta demokrasi Indonesia yaitu pemilihan kepada daerah dan pemilihan presiden tahun 2019. Terkait dengan metafora yang digunakan penulis menemukan dua anak kalimat yang menggunakan metafora, yaitu pada kata 'jual al-Maidah,' dan 'jualan tauhid,' yang diabstarksikan sebagai tindakan menggunakan sentimen agama dalam menarik perhatian masyarakat untuk memilih atau menolak pihak tertentu. Dua agenda ini ditampilkan dalam dua musim demokrasi di Indonesia, yaitu pada pilkada Jakarta 2017 di mana Ahok terjerat kasus penistaan agama, hingga pada pilpress 2019 muncul wacana kriminalisasi ulama dan panasnya pembakaran bendera yang bertuliskan kalimat tauhid, oleh dibakar oleh Banser.

Tweet ketiga diposting oleh akun@saidimin yang secara reprsentasi 
menggunakan tata bahasa proses mental di mana pemilik akun berusaha membentuk kesadaran khalayak bahwa tindak politisasi agama memang sering dilakukan oleh Partai Keadilan Sejahtera (PKS). Relasi yang Nampak dalam cuitan Antara lain: a) PKS dinggap sebagai partai yang memiliki kecenderungan ideologi Islam yag diaktualisasikan melalui pola politisasi simbol dan ritual agama; b) politisasi agama dikaitkan dengan wacana penistaan agama dan juga kriminalisasi Ulama.

\section{Pertarungan Ideologi Organisasi yang Berpengaruh di Masyarakat)}

Dewan Intelejen Nasional AS (National Intelligence Council's/NIC) merilis laporan dalam bentuk dokumen yang berjudul "Mapping the Global Future" pada Desember 2004 (NIC, 2004), dokumen ini berisi perediksi bahwa khilafah Islam akan bangkit kembali. Kekuatan institusi Islam dianggap sebagai ancaman karena jika khilafah bangkit kembali maka akan menghentikan hegemoni, liberalisme serta kapitalisme Barat atas dunia, oleh karena itu Barat berupaya dengan sungguh-sungguh untuk menghalangi upaya kebangkitan khilafah Islamiyah.

Di Indonesia, benih ide khilafah telah ada sejak kemerdekaan 1945 hingga pasca reformasi, Gerakan keagamaan yang cenderung radikal sepertinya memeroleh angin segar untuk berkembang. Gerakan keagamanna seperti ini ditandai dengan tiga hal: a) kembali kepada Islam sebagaimana dilakukan para ulama salaf yang saleh; b) penerapan syariah Islamiyah; dan c) menolak produk Barat (Syam, 2018: 80). Gerakan ini memperoleh momentum yang sangat tepat di tengan euforia demokratisasi dan keterbukaan yang dialami masyarakat, sehingga negara-pun tidak dapat melakukan tindakan yang bersifat represif karena meningkatnya Hak Asasi Manusia.

Bahasa sebagai alat hegemoni memberikan gambaran yang lebih jelas tentang paksaan atau persetujuan sebagai cara kita memandang dunia. Dalam artikel ini sebuah bahasa digunakan oleh suatu kelompok yang merepresentasikan dirinya sebagai pihak yang tidak hanya mampu memenuhi kepentingan sendiri namun juga kebutuhan dan kepentingan kelompok sosial. Kesenjangan ini digerakkan oleh kecenderungan ideologis berbeda yang didukung oleh Nahdlatul Ulama (NU) dan kelompok organisasi keislaman yang telah dilarang di Indonesia, yaitu Hisbut Tahrir.

Ideologi kelompok pertama menentang pembentukan khilafah, serta kukuh mendukung prinsip-prinsip NKRI yang sudah final dan tidak bisa diganggu gugat. Sebaliknya, kelompok kedua mewacanakan Islam sebagai solusi dan ideologi alternatif dari bentuk pemerintahan negara Indonesia berformat republik menjadi 
khilafah. NU menganggap bahwa kelompok-kelompok Islam di antaranya HTI, mendukung dan beroperasi dalam kubu Prabowo (Burhani, 2019).

Selain pertarungan ideologis, persaingan politik juga diwarnai dengan isuisu populis, di mana terdapat aktor-aktor politik yang dapat memobilisasi kelompok sosial yang biasanya terpinggirkan kemudian muncul secara aktif untuk melakukan aksi politik nyata yang kontroversial (Jayanto, 2019). Sudah menjadi rahasia umum, kendati telah resmi dibubarkan, kader-kader HTI masih terus bergerak menyebarkan ideologinya, ideologi transnasionalisme HTI merepresentasikan gerakan "sentrifugalisme" Islam, di mana visi politiknya adalah menyatukan identitas Islam nasional dan lokal yang berserak di bawah otoritas tunggal Khilafah Islamiyah (Hilmy, 2011). Hingga muncul peristiwa pembakaran bendera HTI di garut pada hari santri 22 Oktober 2018 yang kemudian dipolitisasi sampai terjadi benturan antara NU (Banser) dengan HTI. Pertama, Hisbut Tahrir dengan "mimpi khilafahnya" menjadi potensial untuk dibenturkan dengan pancasila dan NKRI dan juga dianggap melawan kesepakatan keberagamaan umat Islam secara umum maka mudah distigmakan negatif, kedua, sebagai organisasi kecil sementara Ansor dengan Bansernya merupakan bagian dari organisasi Nahdlatul Ulama (NU), ormas terbesar di Indonesia. Ketiga, HTI diidentifikasikan sebagai bagian dari pendukung oposisi, dalam hal ini adalah paslon 02 Prabowo Subianto-Sandiaga Uno. Lebih jelasnya, dengan memperburuk citra HTI akan berimbas pada buruknya citra pasangan calon nomor 02 (Rosyid, 2018).

Bersitegang antara HTI dengan Banser juga berimbas pada citra Jokowi dengan isu anti Islam, karena dianggap belum menunjukkan sikap untuk membereskan kekisruhan akibat pembakaran bendera, hal ini dikaitkan dengan aksi bela Islam atas peristiwa penodaan agama oleh Ahok dan juga reuni 212 yang disinyalir terdapat agenda politik menjelang pilpres 2019 (Nathaniel, 2018).
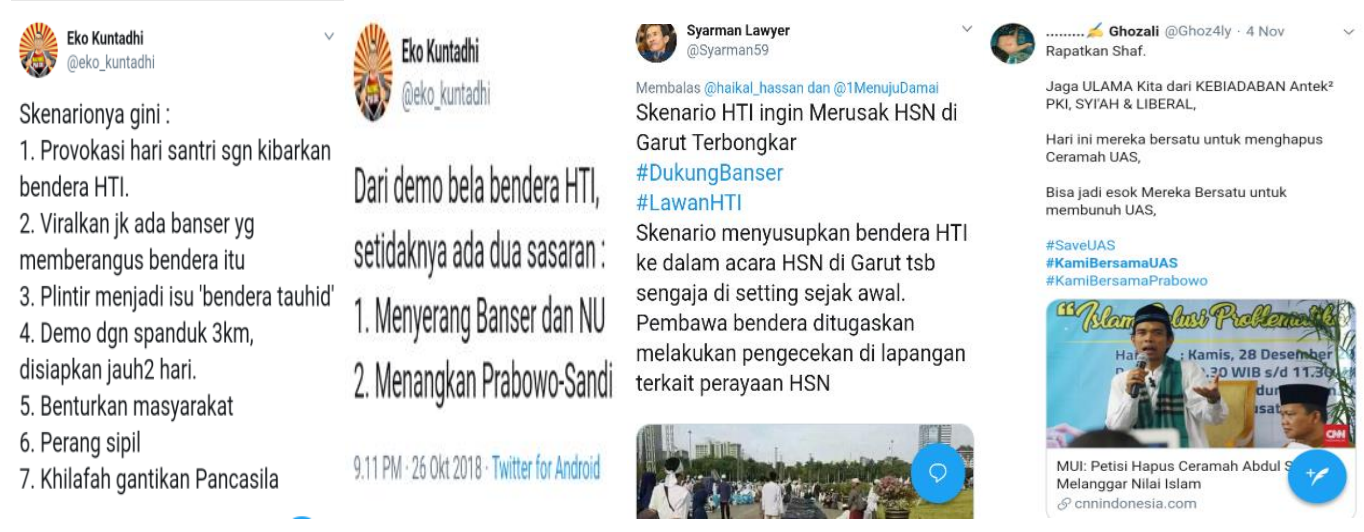
Tweet lainnya dari@Kuntadhi diposting pada 23 Oktober 2018 yang menyatakan bahwa, pembakaran bendera tauhid merupakan skenario yang telah dibuat sendiri oleh HTI untuk menjatuhkan Banser sebagai pelaku, lalu menviralkan untuk membenturkan citra Banser kepada masyarakat sebagai organisasi yang intoleran dan tidak mengindahkan hak asasi manusia, wacana ini juga diperkuat dengan dengan produksi wacana yang disampaikan oleh akun @Syarman59 tentang skenario atau setting peristiwa yang dilakukan oleh HTI sendiri. Selain membenturkan Banser dengan masyarakat sipil, aksi ini juga merupakan kritik terhadap pemerintah dengan wacana kriminalisasi ulama', anti kalimat tauhid atas bebasnya pelaku pembakaran bendera setelah beberapa waktu masuk dalam bui, dan gencarnya aksi gerakan \#2019gantipresiden. Pertarungan wacana dalam fenomena penolakan Ustadz Abdul Somad dalam penelitian ini berujung pada stategi penyerangan serta pertahanan wacana dari masing-masing kubu, karena persoalan afiliasi Ustadz Abdul Somad dapat dimediasi dengan tabayyun dan klarifikasi lewat media, baik tradisional maupun sosial. Namun isu tentang khilafah semakin berkembang hingga menampilkan adanya proses saling menuduh antar oposisi dan petahana.

Dari sekian tweet yang diposting oleh pemilik akun di atas, temuan data makna teks wacana penolakan dakwah Ustadz Abdul Somad, secara representasi, relasi dan juga identitas dapat penulis tampilkan dalam tabel dan grafik di bawah ini.

Tabel 4.1. Wacana yang Muncul dalam Pro-Kontra Penolakan UAS

\begin{tabular}{|l|l|}
\hline Wacana Kontra-Penolakan Dakwah Ustadz Abdul Somad \\
\hline Hastags yang dipakai & Wacana yang dimunculkan \\
\hline \#SaveUstadzAbdulSomad & -Persekusi di Bali \\
\#KamiBersamaUAS & -Persekusi di Hongkong \\
\#BubarkanBanser & -Akun Instagram diblokir \\
\#PrabowoUAS & -Pencalonan UAS menjadi \\
\#2019gantipresiden & Cawapres mendampingi Prabowo \\
\#StopIntimidasiUlama & Subianto \\
\#KamiBersamaUlama & -Atribut Bertuliskan Kalimat \\
\#KamiBersamaHRS & Tauhid \\
\#KamiBersamaNenoWarisman & -Banser Penyebab Persekusi UAS \\
& -Banser Pembakar Bendera Tauhid \\
& -Kritik terhadap Pemerintahan \\
& Joko Widodo \\
& -Intimidasi Ulama (Rizieq Syihab, \\
& Neno Warisman) \\
\hline
\end{tabular}




\begin{tabular}{|l|l|}
\hline Wacana Pro-Penolakan Dakwah Ustadz Abdul Somad \\
\hline Hastags yang dipakai & Wacana yang dimunculkan \\
\hline \#SavePancasila & -Afiliasi UAS dengan HTI \\
\#StopProvokasi & -Kriminalisasi Ulama adalah \\
\#NKRIHargaMati & Framing oposisi Kubu Prabowo \\
\#LawanHTI & (Rizieq Syihab, Neno Warisman, \\
\#TolakRadikalisme & Bahar bin Smith) \\
\#02vsNU & -Pilkada Jual Al-Maidah (Kasus \\
\#2019TetapJokowi & Penistaan Agama oleh Ahok) \\
\#02PermainkanAgama & -Pilpres Jual Kalimat tauhid \\
\#NenoGantiTuhan & -Konsep NKRI Bersyariah \\
\#Situwaras & \\
\hline
\end{tabular}

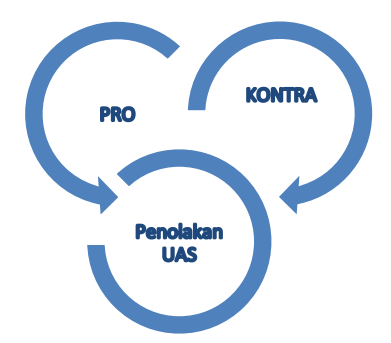

Gambar 4.28 Pro-Kontra Penolakan UAS

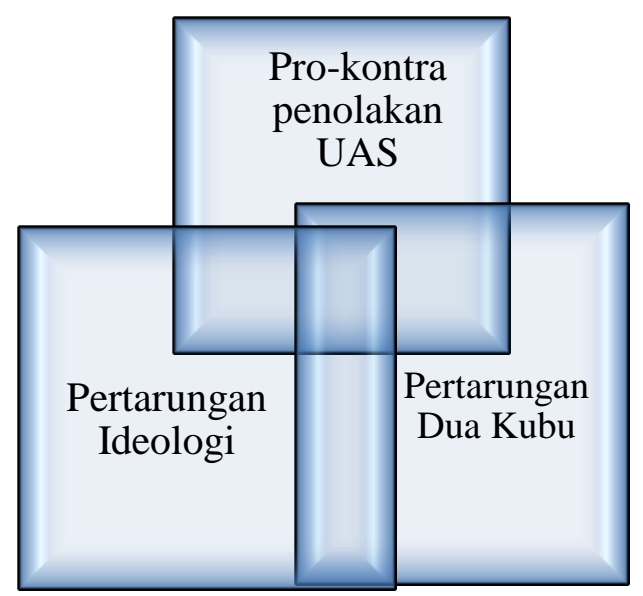

Gambar 4.29 Pertarungan Wacana Penolakan UAS 


\section{SIMPULAN}

Berdasarkan pada analisis wacana kritis dan nilai hegemoni dalam wacana pro-kontra penolakan dakwah Ustadz Abdul Somad, berikut poin-poin yang dapat penulis paparkan, Antara lain: (1) Persoalan afiliasi Ustadz Abdul Somad dapat dimediasi dengan tabayyun dan klarifikasi lewat media, baik tradisional maupun sosial. Namun isu tentang khilafah semakin berkembang hingga menampilkan adanya proses saling menuduh antar pihak-pihak yang terlibat dalam wacana kebangkitan khilafah; 2) Wacana penolakan Ustadz Abdul Somad di media sosial dalam penelitian ini memuat kecenderungan dari dua ideologi berbeda yaitu Nahdlatul Ulama (NU), dan Hisbut Tahrir Indonesia (HTI). Ideologi kelompok pertama menentang pembentukan khilafah, serta kukuh mendukung prinsipprinsip NKRI yang sudah final dan tidak bisa diganggu gugat. Sebaliknya, kelompok kedua mewacanakan Islam sebagai solusi dan ideologi alternatif dari bentuk pemerintahan negara Indonesia berformat republik menjadi khilafah; (3) Selain itu, kecenderungan yang lainnya juga dipengaruhi oleh kepentingan politik, di mana sebelumnya berdasarkan hasil ijtima' ulama, nama Ustadz Abdul Somad (UAS) diusulkan sebagai calon wakil presiden mendampingi Prabowo Subianto. Terkait dengan pengusulan namanya, UAS menghormati rekomendasi yang diberikan oleh ijtima' ulama, dan menyatakan bahwa ingin istiqomah di jalan dakwah dan pendidikan saja; 4) Sitegang Antara HTI dengan Banser berimbas pada citra kubu Prabowo maupun Jokowi dengan adanya pertarungan isu. HTI diidentifikasikan sebagai bagian dari pendukung oposisi, dalam hal ini adalah paslon 02 Prabowo Subianto-Sandiaga Uno. Lebih jelasnya, dengan memperburuk citra HTI akan berimbas pada buruknya citra pasangan calon nomor 02. Sedangkan imbasnya pada kubu jokowi dengan isu anti Islam, karena dianggap belum menunjukkan sikap untuk membereskan kekisruhan akibat pembakaran bendera, hal ini dikaitkan dengan aksi bela Islam atas peristiwa penodaan agama oleh Ahok dan juga reuni 212 yang disinyalir terdapat agenda politik menjelang pilpres 2019. Saran dari penelitian ini, bagi khalayak media massa maupun media sosial, untuk tidak berpikir praktis dan cenderung menelan informasi apa adanya bahkan bersikap skeptis terhadap informasi yang muncul dalam media massa atau media sosial, tetapi justru bersikap aktif dan kritis agar setiap elemen masyarakat dapat saling mendukung mencapai persatuan Indonesia yang kondusif. 


\section{DAFTAR PUSTAKA}

\section{Buku}

Arifin, S. dan Maulana, M. T. (2017). Madzhab Ukhuwah. Pontianak: CV. Razka Pustaka.

Azizi, M. H. (2017). Hegemoni dalam Wacana Media (Pertarungan Wacana Muktamar Nahdlatul Ulama ke-33 dengan muktamar Muktamar Muhammadiyah ke-47 pada Surat Kabar Harian Tempo, dalam Antologi Kajian Islam, 30. Tesis-Surabaya: Pascasarjana UINSA Press.

Barker, C. (2011). Cultural Studies, Terj. Nurhadi, Cet. 7. Bantul: Kreasi Wacana. Burton, G. (2012). Media dan Budaya Populer. Yogyakarta: Jalasutra.

Departemen Pendidikan Nasional. (2008). Kamus Besar Bahasa Indonesia Pusat Bahasa. Jakarta: PT. Gramedia Pustaka Utama.

Eriyanto (2015). Analisis Wacana Kritis: Pengantar Analisis Teks Media. Yogyakarta: LKiS.

Ghofar, M. A. (2015). Salah Kaprah Khilafah. Yogyakarta: Deepublish, 2015.

Haryatmoko. (2016). Critical Discorse Analysis (Analisis Wacana Kritis): Landasan Teori, Metodologi, dan Penerapan. Jakarta: Rajawali Pers.

Hosen, N. (2018). Islam Yes, Khilafah No!, Jilid 2. Yogyakarta: Suka Press.

Ives, P. (2004). Language and Hegemony in Gramsci. London: Pluto Press.

Jorgensen, M.W dan Louise, J. P. (2007) Analisis Wacana: Teori dan Metode, Terj. Imam Suyitno dkk. Yogyakarta: Pustaka Pelajar.

Kriyantono, R. (2012). Teknik Praktis Riset Komunikasi, Cet 6. Jakarta: Kencana.

NIC: Report of the National Intelligence Council's 2020 Project. (2004). Mapping The Global future. Pittsburgh: Government Printing office (GPO).

Somad, A. (2018). 37 Masalah Populer, cet 8. Riau: Tafaqquh Media, 2018.

Syam, N. (2012). Tantangan Multikulturalisme Indonesia dari Radikal menuju Kebangsaan. Yogyakarta: Kanisius.

Weiss, G and Ruth Wodak. (2003). Critical Discourse Analysis: Theory and Interdisiplinarity. New York: Palgrave Macmilan.

\section{Jurnal dan website}

ARN. (2018, Juli 25). Corong HTI! Semarang Tolak Tabligh Akbar Ustadz Abdul Somad. Retreived November 09, 2018, from https://arrahmahnews.com

Bambang S. (2018, 1 Januari). Kupas Tuntas Ustadz Abdul Somad (1). From www.hidayatullah.com (Retreived Januari 1, 2019)

Burhani, A. N. (2019, 26 Maret). Nahdlatul Ulama and the Framing of an Ideological Battle in the 2019 Indonesian Elections. Retreived Maret 19, 2019, from www.iseas.edu.sg

Debita Matongdang. (2017, Desember 12). Ustad Somad ditolak di Bali, Salah Satu Pelakunya anggota DPD. Retreived November 09, 2018, from https:// news.detik.com 
Esthi Maharani. Soal Ceramah UAS ditunggangi, Busyo Muqoddas: tak Ada Bukti. Retreived Februari, 2019, from https://www.voa-islam.com

Hafsi, N. dkk. (2017). Perpersentasi Kepemimpinan Calon Presiden di Twitter. Jurnal Aspikom. 270-24

Hilmy, M. (2011). Akar-Akar Transnasionalisme Isam Hisbut Tahrir Indonesia (HTI). Islamica, 6 (1).

Ibrahim, G. M. (2018, 07 Agustus). Apa Kabar Pencalonan Ustadz Abdul Somad jadi Cawapres Prabowo?. Retreived, Januari 27, 2019, from: m.detik.com

Jayanto, D. D. (2019). Mempertimbangkan Fenomena Populisme Islam di Indonesia dalam Perspektif Pertarungan Diskursif: Kontestasi Wacana Politik antara Gerakan Nasional Pengawal Fatwa Ulama (GNPF-ULAMA) dan Nahdlatul Ulama (NU). Jurnal Filsafat, 29 (1), 1-25

Kurniawan, B. (2018). Politisasi Agama di tahun Politik: Politik Pasca-Kebenaran di Indonesia dan Ancaman bagi Demokrasi. Jurnal Sosiologi Agama, 133154

Mumazziq, Z. R. (2017, Desember 29). Membandingkan Abdul Somad dengan Kiai Said Aqil adalah 'Njomplang.' Retreived Desember 28, 2018, from: www.dutaislam.com,

Nathaniel, F. (2018, 2 Oktober). Menyeret Kasus Pembakaran bendera ke Reuni 212 dan Imbas Politiknya. Retreived Mei 03, 2019, from: dalam https://tirto.id

Quraisy, K. (2018) Profil Biografi Ustadz Abdul Somad. Retreived November 09, 2018, from https://www.fiqihmuslim.com

Rahadian, L. (2018, 08 Agustus). Untung Rugi Prabowo Pilih Somad sebagai Cawapres di Pilpres 2019. Retrieved Januari 27, 2019, from tirto.id

Rosyid, T. (2018, 31 Oktober). Pembakaran Bendera Tauhid, Persekusi HTI, dan Pilpress 2019, dalam. Retreived Mei 03, 2019, from: https://voa-islam.com

Sasongko, J. Abdul Somad ditolak Masuk Hongkong. Retreived Desember 09, 2018, from http://n.cnnindonesia.com

Setiawan, W. (2018, 07 September). Kata GP Ansor Jepara Soal UAS Batalkan Ceramah Karena Intimidasi. Retreived Februari 12, 2019, from https://news.detik.com.

Solusi. (2017, Desember 24). Ustaz Abdul Somad ditolak Masuk ke Hong Kong. Retreived November 09, 2018, from https://www.kaskus.co.id

SUO2. (2019, 9 Desember). Sempat ditolak, Ustadz Somad Akhirnya lancar Ceramah di Bali. Retreived Januari 19, 2019, from: https:/seruji.co.id

Tafaqquh Video. (2018, 30 Juli). Ustadz Abdul Somad, Lc., MA ditanya tentang Cawapres- begini Jawabannya Retreived Februari 2, 2019, from www.youtube.com

Tornberg A\& Tornberg P. (2016). Muslims in Social Media Discourse: Combining Topic Modeling and Critical Discourse Analysis. Journal of Discourse, Context, and Media, 13, 132-134.

Voa Islam. UAS diintimidasi, Forum Silaturrahim Alumni Mesir Angkat Bicara. Retreived Februari 12, 2019, from https://www.voa-islam.com 